\title{
Performance of participatory and non-participatory farmers of integrated crop management project at Pirganj upazila under Thakurgaon district
}

\author{
M. C. Sumy, M. A. Halim, M. R. Hasan and M. R. Begum \\ Department of Basic Science, Chittagong Veterinary and Animal Sciences University, Chittagong-4202, Bangladesh
}

\begin{abstract}
This study examines technical efficiency between Participatory \& Non- Participatory farmers under Integrated Crop Management project (ICM) in the north-west region of Bangladesh. Sixty farmers of which 30 participatory \& 30 nonparticipatory were selected following stratified random sampling technique from four villages under pirganj upazila in Thakurgaon district. ICM project participatory farmers received higher net returns than the non-participatory farmers from selected crop production. Participatory farmers were technically more efficient than non- participatory farmers. Getting membership status of non- participatory farmers was suggested to be an important factor in removing technical inefficiency.
\end{abstract}

Keywords: Technical efficiency, Participatory, Non-participatory

\section{Introduction}

The measurement of farming efficiency in agriculture development exercises in developing countries, since it gives pertinent information useful for making sound management decision in resource allocations and formulating agricultural policies and institutional improvements. Usually two types of efficiency namely, technical and allocative efficiencies are familiar in the area of agricultural farming.

Technical efficiency refers to the ability of a firm to obtain maximum output of a given set of inputs under certain production technology whereas allocative efficiency reflects the ability of a farm to use the inputs in optimal proportions, given their input prices; and a combination of these two measures provides a measure of economic efficiency. In Bangladesh, where resources are scarce and opportunities for new technologies are lacking, efficiency (or inefficiency) studies will be able to show that it is possible to increase productivity growth new investment or developing new technology.

It is generally assumed that in Bangladesh farmers are inefficient at producing paddy crops and there are significant efficiency differences among region to region, farm groups and also crops. Sharif and Dar (1996) found higher technical efficiency in producing T. aman than Aus or MV boro. Rahman et al. (1999) investigated rice production in Bangladesh using Cobb-Douglas stochastic production function and found that technical inefficiency effects decrease significantly with the increase in the magnitudes of farmer's age, experience, extension contact and farm size. The study also reveals that there are significant technical inefficiency effects in the production of all rice crops and the random component of the inefficiency effects explains that a significant portion of the difference between the observed output and the maximum production frontier output is caused by differences in farmers' levels of technical efficiency. Rashid and Chen (2002) examined technical efficiency of shrimp farmers of south-eastern and southwestern Bangladesh taking into account three farming methods viz extensive, improved extensive and semi-intensive. Sources of yield variations, i.e., production input, technical efficiency and other factors in all the three methods were investigated and factors affecting technical inefficiency were also analyzed simultaneously with the production frontiers using maximum likelihood method. The study showed that $85 \%, 61 \%$ and $87 \%$ variation, respectively in output among the farming methods in shrimp cultivation was due to differences in technical efficiency. Land, fry and feed have significant influence on the level of shrimp production.

After the measurement of efficiency differences, proper measures can be undertaken to reduce them. It is equally important to identify farm-specific factors, which influence inefficiency effects. In this study, farming efficiency for participatory and non-participatory resource-poor farmers of ICM project has been estimated. The findings of this study will be useful in a wide range of decision making situations affecting the development of agriculture in this country and also provide information to planners, government, extension workers, farmers and to those concerned with research on farm resource use for livelihood improvement of resource-poor farmers in Bangladesh. 


\section{Materials and Methods}

\section{Sampling Procedure and the data}

The stratified random sampling technique was used in the study. Four villiages namely; Dohara,Shibpur,Uttar Shibpur and Sordarpara from pirojpur upazila were selected by simple random sampling. In total 60 farmers of which 30 participatory and 30 non-participatory (The farmers who are not related to ICM project) farmers were randomly selected for the study. It should be noted here that initially population lists of the selected area was collected from the concerned officials of ICM project.

\section{Field Survey}

The data was collected from February to May 2003. The questionnaire was constructed to ask for details about the crop operation on the farms. In particular, there was interest in crop varieties grown, the yields obtained, the use of inputs, such as fertilizer, seed, irrigation, pesticides etc. Information was also obtained on some basic personal characteristics of the sample farmers. The output and input data were obtained on a per hectare basis in the survey.

\section{Computerization}

A data base was developed using the computer package Excel. Different data base files were designed to enter data on different aspects, each file with a common field for the farmer identification number. The survey data were analyzed to obtain summaries, averages, counts, minia, maxima and standard deviations of the important data pertaining to farm families. The data so entered in Excel, were then transferred to another computer package SPSS 11.5 for using in the FRONTIER 4.1 program.

\section{Analytical technique}

To assess the profitability of the concerned crops of individual participatory and non-participatory sample farmers the following algebraic equation and/or $\pi$ (i.e., profit) equation was followed:

$\Pi=$ Per hectare net return or profit from the relevant crops/vegetables $(T k / h a) ;$

$\mathrm{P}_{\mathrm{r}}=$ Per unit price of the concerned crops/vegetables $(\mathrm{Tk} / \mathrm{ha})$;

$\mathrm{Q}_{\mathrm{r}}=$ Per hectare yield of the concerned crops/vegetables $(\mathrm{kg} / \mathrm{ha})$;

$\mathrm{P}_{\mathrm{b}}=$ Per unit price of by product $(\mathrm{Tk} / \mathrm{kg})$;

$\mathrm{Q}_{\mathrm{b}}=$ Total quantity of the by product ( $\left.\mathrm{kg} / \mathrm{ha}\right)$;

$\mathrm{Px}_{\mathrm{i}}=$ Per unit price of the $\mathrm{i}_{\mathrm{th}}$ inputs used for producing the concerned crops/vegetables (Tk/unit);

$\mathrm{x}_{\mathrm{i}}=$ Total quantities of the $\mathrm{i}_{\mathrm{th}}$ inputs used for producing per hectare crops/vegetables;

TFC= Total fixed costs involved in producing per hectare crops/vegetables; $\mathrm{i}=1,2,3, \ldots \ldots \ldots, \mathrm{n}$; and $\mathrm{n}=$ Number of inputs used.

Farrel (1957) suggested a method of measuring the technical efficiency of a firm in an industry by estimating the production function of firms which are "fully-efficient" (i.e., a frontier production function) and the technique has generally been preferred in the agricultural economics literature (Coelli and Battese, 1996). A Cobb-Douglas functional form is employed to examine rice production technology in this study.Kopp and Smith (1980) suggested that functional form has limited effects on empirical efficiency measurement. The Cobb-Douglas form has been used in many empirical studies, particularly those relating to developing country agriculture.

The Cobb-Douglas functional form also meets the requirement of being self-dual, allowing an examination of economic efficiency (Xiaosong and Scott, 1998). This is, in fact, an econometric technique was used to estimate frontier production function and thus, measurement of the efficiency which involves both (i) Allocative efficiency which reflects the ability of a firm to use the inputs in optimal proportions, given their respective prices; (ii) Technical efficiency that reflects the ability of a farmer to obtain maximum output from a given set of inputs. In the second stage, these predicted technical inefficency effects (or technical efficiencies) are related to farm-specific factors using ordinary least-quare regression ( Coelli and Battese, 1996). 


\section{Model Specification}

The stochastic frontier and inefficiency model specification were:

$\ln \left(Y_{i}\right)=\ln \beta_{0}+\beta_{1} \ln X_{1 i}+\beta_{2} \ln X_{2 i}+\beta_{3} \ln X_{3 i}+\beta_{4} \ln X_{4 i}+\beta_{5} \ln X_{5 i}+\beta_{6} \ln X_{6 i}+\beta_{7} \ln X_{7 i}+\beta_{8} \ln X_{8 i}+\beta_{9} \ln X_{9 i}+\beta_{2} \ln X_{2 i}+\left(V_{i}-\right.$ $\left.\mathrm{U}_{\mathrm{i}}\right)$

Where,

$Y$ represent Per hectare yield of crops $(\mathrm{Kg} / \mathrm{ha})$;

$\beta_{0}$ Indicates Constant or intercept;

$\mathrm{X}_{1}$ represents quantity of human labour used (man days/ha);

$\mathrm{X}_{2}$ represents quantity of bullock used (pair days/ha);

$\mathrm{X}_{3}$ represents quantity of quantity of seed/seedlings used (Tk/ha);

$\mathrm{X}_{4}$ represents quantity of manure used $(\mathrm{kg} / \mathrm{ha})$;

$X_{5}$ represents quantity of Urea used $(\mathrm{kg} / \mathrm{ha})$;

$\mathrm{X}_{6}$ represents quantity of TSP used $(\mathrm{kg} / \mathrm{ha})$;

$\mathrm{X}_{7}$ represents amount of muriate of potash used $(\mathrm{kg} / \mathrm{ha})$;

$\mathrm{X}_{8}$ represents cost of irrigation ( $\left.T k / \mathrm{ha}\right)$;

$\mathrm{X}_{9}$ represents cost of pesticides (Tk/ha);

$\beta_{\mathrm{i}}=$ Unknown parameters to be estimated;

In = Natural logarithm;

$V_{i}$ and $U_{i}=V_{i}$ is an independently and identically distributed random error and $U_{i}$ is a non-negative variable, associated with technical inefficiency in production; $I=1,2, \ldots \ldots \ldots \ldots 60$;

Most farmers did not use power tiller and pesticides for T. aman in the study area. These variables were, therefore, not included in the model.

The model for the technical enefficiency effects in the stochastic frontier of equation (3) is defined by $U_{i}=$ $\delta_{0}+\delta_{1} z_{1 i}+\delta_{2 i}+\delta_{3} z_{3 i}+\delta_{4} z_{4 i}+\delta_{5} z_{5 i}+\delta_{6} z_{6 i}+\delta_{7} z_{7 i}$

Where,

$\mathrm{z}_{1}$ represents age of the selected farmers (years);

$z_{2}$ represents year of schooling of the selected farmers (years);

$\mathrm{z}_{3}$ represents cultivated areas (ha);

$z_{4}$ represents experience of the selected farmers in farming (years);

$\mathrm{z}_{5}$ represents transplanting space (inches);

$\mathrm{Z}_{6}$ represents period gap between uprooting of seedling and transplanting (days);

$\mathrm{z}_{7}$ represents membership status (Dummy variable which receives ' 1 ' for participatory ' 0 ' for nonparticipatory farmers);

$\delta_{0}=$ Constant;

$\delta_{\mathrm{i}}=$ Unknown parameters to be estimated;

$\mathrm{I}=1,2, \ldots \ldots . ., 60$.

The $\beta$ - and $\delta$ - are coefficients fo unknown parameters to be estimated, together with the variance parameters which are expressed in terms of

$$
\begin{aligned}
\sigma^{2} & =\sigma^{2}{ }_{u}+\sigma^{2}{ }_{v} \\
\text { and } y & =\sigma^{2}{ }_{u} / \sigma^{2}
\end{aligned}
$$

The technical efficiency of a farmer at a given single period of time is defined as the ratio of the observed output to the frontier output which could be produced by a fully-efficient firm, in which the inefficiency effect is zero. The technical efficiency of the ith farmer in the single period of observation can be shown to be equal to $T E_{i}=\exp \left(-U_{i}\right)$

The y parameter has value between zero and one. The parameters of the stochastic frontier production function model are estimated by the method of maximum likelihood, using the computer program, FRONTIER Version 4.1 (see Coelli, 1992 and 1994). 
It is worth mentioning here that the above model for the inefficiency effects (equation 4) can only be estimated if the inefficiency effects are stochastic and have a particular distribution specification. Hence, it is important to test the null hypothesis that the variables in the model for the inefficiency effects are not present, $\mathrm{H}_{0}: \mathrm{y}=\delta_{0}=---=\delta_{7}=0$ and the coefficients of the variables in the model for the inefficiency effects are zero, $H_{0}: \delta_{1}==---\delta_{7}=0$. These null hypothesis can be tested using the generalized likelihood ratio statistic $L R$, defined by

$L R=-2\left\{\ln \left[L\left(\mathrm{H}_{0}\right) / L\left(\mathrm{H}_{1}\right)\right]\right\}=-2\left\{\ln \left[\mathrm{L}\left(\mathrm{H}_{0}\right)\right]-\ln \left[\mathrm{L}\left(\mathrm{H}_{1}\right)\right]\right\}$

Where, $L\left(\mathrm{H}_{0}\right)$ and $L\left(\mathrm{H}_{1}\right)$ are the values of the likelihood function under the null and alternative hypothesis, $\mathrm{H}_{0}$ and $\mathrm{H}_{1}$, respectively.

\section{Results and Discussion}

\section{Returns from crop cultivation}

The ICM project participatory farmers learned higher net return from all the selected T. Aman, MV boro, potato and wheat crops than those of non-participatory farmers. ICM participatory farmers of Pirgonj area obtained the highest per ha net return (Tk. 56305.00) from potato cultivation followed by T. Aman (Tk. 22050.00/ha) and MV boro (Tk.21234/ha). The wheat farmers earned the lowest per ha net returns of Tk. 7840.00. Potato growers in the non-participatory group also earned the highest per ha net return (Tk. 50117.00) followed by T. Aman ( Tk. 14109.00) and MV boro (Tk. 12383.00). Like the participatory wheat growers, the non-participatory wheat growers also earned the lowest per ha net returns (Tk. 3377.00) (Table 1).

Table 1. per hectare net return and BCR of different crops in Pirganj Upazila.

\begin{tabular}{|l|c|c|c|c|}
\hline \multirow{2}{*}{ crops } & \multicolumn{2}{|c|}{ Participatory } & \multicolumn{2}{c|}{ Non-participatory } \\
\cline { 2 - 5 } & Net return (Tk/ha) & BCR (Undiscounted) & Net return (Tk/ha) & BCR (Undiscounted) \\
\hline T. Aman & 22050.00 & 2.61 & 14109.00 & 2.05 \\
\hline MV boro & 21234.00 & 1.76 & 12383.00 & 1.51 \\
\hline Potato & 56305.00 & 2.20 & 50117.00 & 2.14 \\
\hline Wheat & 7840.00 & 1.53 & 3377.00 & 1.22 \\
\hline
\end{tabular}

Source: MS thesis

It is evident that the undiscounted BCR of participatory T. Aman farmers was the highest (2.61) followed by MV boro (1.76), Potato (2.20), and wheat (1.53). Where the non-participatory potato growers got the highest BCR (2.14). Although the BCR of non-participatory T. Aman farmers was quite high (2.05), it was relatively lower than the participatory farmers.

\section{Model analysis}

OLS Estimates of Cobb-Douglas Production Function: Ordinary least square estimates of the parameters show the average performance of the sample farmers. Farmers of Pirgonj used excessive amount of urea in T. Aman cultivation.

Table 2. Ordinary least square (OLS) estimates of a Cobb-Douglas (C-D) production function for Pirgonj upazila

\begin{tabular}{|l|c|c|c|c|c|}
\hline \multirow{2}{*}{ Variable } & \multirow{2}{*}{ parameters } & \multicolumn{2}{|c|}{ T. Aman paddy } & \multicolumn{2}{c|}{ MV boro paddy } \\
\cline { 3 - 6 } & & Co-efficient & Standard error & Co-efficient & Standard error \\
\hline Intercept & $\beta_{0}$ & $2.578^{* * *}$ & 1.090 & $2.170^{* *}$ & 0.992 \\
\hline Human labour & $\beta_{1}$ & $0.493^{*}$ & 0.306 & $-0.113^{*}$ & 0.064 \\
\hline Bullock & $\beta_{2}$ & 0.080 & 0.269 & -0.223 & 0.147 \\
\hline Seedlings & $\beta_{3}$ & -0.412 & 0.446 & 0.021 & 0.041 \\
\hline Manure & $\beta_{4}$ & $0.737^{* *}$ & 0.333 & $0.121^{* *}$ & 0.183 \\
\hline Urea & $\beta_{5}$ & $-0.541^{*}$ & 0.301 & $1.288^{* * *}$ & 0.397 \\
\hline TSP & $\beta_{6}$ & 0.358 & 0.305 & $1.644^{* * *}$ & 0.279 \\
\hline MP & $\beta_{7}$ & $0.941^{* * *}$ & 0.127 & $1.062^{* * *}$ & 0.274 \\
\hline Irrigation & $\beta_{8}$ & 0.121 & 0.098 & 0.292 & 0.219 \\
\hline Pesticide & $\beta_{9}$ & - & - & -0.006 & 0.095 \\
\hline
\end{tabular}

${ }^{* * *}$ significant at $1 \%,{ }^{* *}$ significant at $5 \%,{ }^{*}$ significant at $10 \%$ 
The estimated value of the coefficient of human labour, manure, MP were positive and statistically significant at 10,5 and 1 percent level of significance, respectively. The estimated values of the coefficients of seedling and urea used for $\mathrm{T}$. aman was negative but significant. This indicated that these two inputs were important for T. Aman cultivation but the farmers would have used these inputs excessively. In MV boro paddy production, the co-efficient of human labour, was negative but significant, indicating excessive use of these inputs. The coefficient of manure, urea, TSP, MP have positive and significant impact on MV boro production (Table 2).

\section{Maximum likelihood Estimate}

The estimates of the Stochastic frontier shows the best practice i.e. efficient use of available technology. The estimated values of the co-efficient of human labour, manure and MP were positive and significant effect on T. Aman cultivation in Pirganj area. The co-efficient of seedlings has got a negligible negative impact on per hectare yield of T. Aman paddy due to overuse of this input since farmers of Pirganj are thought that more use of seedlings would give higher yield, which was a wrong idea. Irrigation water was found to be an important input for successful production of T. Aman paddy.

Human labour had significant impact on MV Boro production. But this input was excessively used in Pirgonj where the estimated value of co-efficient was negative. Bullock power was also excessively used in MV boro cultivation. Urea, TSP, MP and irrigation water had positive and significant impact on MV Boro cultivation in Pirganj area. Excessive use of pesticides has negative impact on Boro production (Table 3).

Table 3. Maximum likelihood estimates of parameters of C-D stochastic frontier production function and technical inefficiency effect model for T. Aman and MV boro cultivation for Pirganj farmers

\begin{tabular}{|c|c|c|c|c|c|}
\hline \multirow[t]{2}{*}{ Variable } & \multirow[t]{2}{*}{ parameters } & \multirow{2}{*}{$\begin{array}{l}\text { T. Aman paddy } \\
\text { Co-efficient }\end{array}$} & \multirow[b]{2}{*}{$\begin{array}{l}\text { Standard } \\
\text { error }\end{array}$} & \multicolumn{2}{|c|}{ MV boro paddy } \\
\hline & & & & Co-efficient & $\begin{array}{c}\text { Standard } \\
\text { error }\end{array}$ \\
\hline Intercept & $\beta_{0}$ & $2.19^{* *}$ & 1.002 & $2.110^{\star *}$ & 0.962 \\
\hline Human labour & $\beta_{1}$ & $0.741^{*}$ & 0.397 & $-0.134^{*}$ & 0.081 \\
\hline Bullock & $\beta_{2}$ & 0.006 & 0.257 & -0.211 & 0.155 \\
\hline Seedlings & $\beta_{3}$ & -0.318 & 0.456 & 0.041 & 0.033 \\
\hline Manure & $\beta_{4}$ & $0.667^{\star \star \star}$ & 0.243 & $0.292^{*}$ & 0.172 \\
\hline Urea & $\beta_{5}$ & $-0.523^{*}$ & 0.275 & $1.205^{\star * *}$ & 0.393 \\
\hline TSP & $\beta_{6}$ & 0.305 & 0.281 & $1.468^{\star \star \star}$ & 0.297 \\
\hline MP & $\beta_{7}$ & $0.189^{*}$ & 0.105 & $0.917^{\star \star \star}$ & 0.262 \\
\hline Irrigation & $\beta_{8}$ & $0.176^{*}$ & 0.93 & $0.328^{*}$ & 0.203 \\
\hline \multirow[t]{2}{*}{ Pesticide } & $\beta_{9}$ & - & - & -0.009 & -0.088 \\
\hline & \multicolumn{4}{|c|}{ Inefficiency model } & \\
\hline Intercept & $\delta_{0}$ & 2.278 & 0.9037 & 0.270 & 0.548 \\
\hline Age & $\delta_{1}$ & 0.0018 & 0.009 & -0.011 & 0.010 \\
\hline Education & $\delta_{2}$ & $0.651^{* \star *}$ & 0.069 & $0.022^{* *}$ & 0.011 \\
\hline Farm size & $\delta_{3}$ & -0.987 & 0.712 & $-0.534^{*}$ & 0.303 \\
\hline Experiences & $\delta_{4}$ & -0.015 & 0.0106 & 0.023 & 0.017 \\
\hline $\begin{array}{l}\text { Transplanting } \\
\text { space }\end{array}$ & $\delta_{5}$ & $-0.197^{* *}$ & 0.088 & -0.007 & 0.051 \\
\hline Transplanting gap & $\delta_{6}$ & -0.030 & 0.204 & -0.040 & 0.051 \\
\hline $\begin{array}{l}\text { Membership status } \\
\text { (Dummy) }\end{array}$ & $\delta_{7}$ & $-1.204^{*}$ & 0.708 & $-1.107^{* *}$ & 0.527 \\
\hline & $\delta^{2}$ & $\begin{array}{c}0.148^{* * *} \\
-\end{array}$ & 0.052 & $0.031^{* * *}$ & 0.0060 \\
\hline Parameters & Y & 0.140 & 0.313 & 0.315 & 0.221 \\
\hline $\begin{array}{ll}\text { Log likelihood } \\
\text { function }\end{array}$ & & -24.156 & - & 25.650 & - \\
\hline
\end{tabular}

${ }^{* * *}$ significant at $1 \%,{ }^{* *}$ significant at $5 \%,{ }^{*}$ significant at $10 \%$ 
The estimated results indicate that technical inefficiency decreases as the age of farmers increase in case of MV boro paddy. The positive sign on age of T. Aman farmers of Pirganj areas indicated technical inefficiency of older farmers. The co-efficient of farm size in the inefficiency model was negative which indicated that technical inefficiency of both the T. Aman and MV boro producing farmers decreases as the farm size increases.

The estimated value of the co-efficient of education in T. Aman and MV boro was unexpected but significantly positive value. Experience of the farmers has a negative effect upon the inefficiency effects for T. Aman production. This means that the inefficiency effects decrease with the increase of the experiences of farm operators of T.Aman rice. That is, technical efficiency increased with the increase of experiences of the farmers. The experienced farmers are more efficient than less experienced ones in managing and allocating productive resources.

The coefficients of membership status for T. Aman and MV boro growing farmers were negative and statistically significant. It means that participatory farmers were technically more efficient than nonparticipatory farmers, i.e. the participatory farmers were more productive than non-participatory farmers.

The y parameter associated with the variances in the stochastic frontier is positive but not significant for rice crops. It indicates that there are little inefficiency effects in the rice crops production and the random component of the inefficiency effects makes an insignificant contribution in the analysis of agricultural production. This result is not desirable since three is remarkable inefficiency among the farmers of T.Aman \& MV Boro paddy.

The estimates of $\boldsymbol{\sigma} \mathbf{2}$ (the ratio of farm specific technical efficiency to the total variance of output) for T.Aman \& MV Boro paddy were significant at $1 \%$ level.These suggest that the technical efficiency effects were a momentous component to total variability of the yield of paddy crops.Log likelihood function of T.Aman \& MV Boro paddy were large and significantly different from zero, indicated a good fit and the correctness of the specific distribution assumtion. Therefore, excluding inefficiency factors or traditional production function was not an adequate representations and/or explanations of the research data.

\section{Efficiency Scores of the Pirganj farmers for T.Aman \& MV Boro paddy}

Stochastic frontier production function was estimated for this study to determine technical efficiency. In case of the participatory farmers, mean technical efficiency of pirganj participatory and non- participatory T.Aman farmers were 0.90 and 0.77 , respectively. it indicated that the participatory $\mathrm{T}$. Aman farmers of pirganj area were about 13 percent more efficient than non participatory farmers.

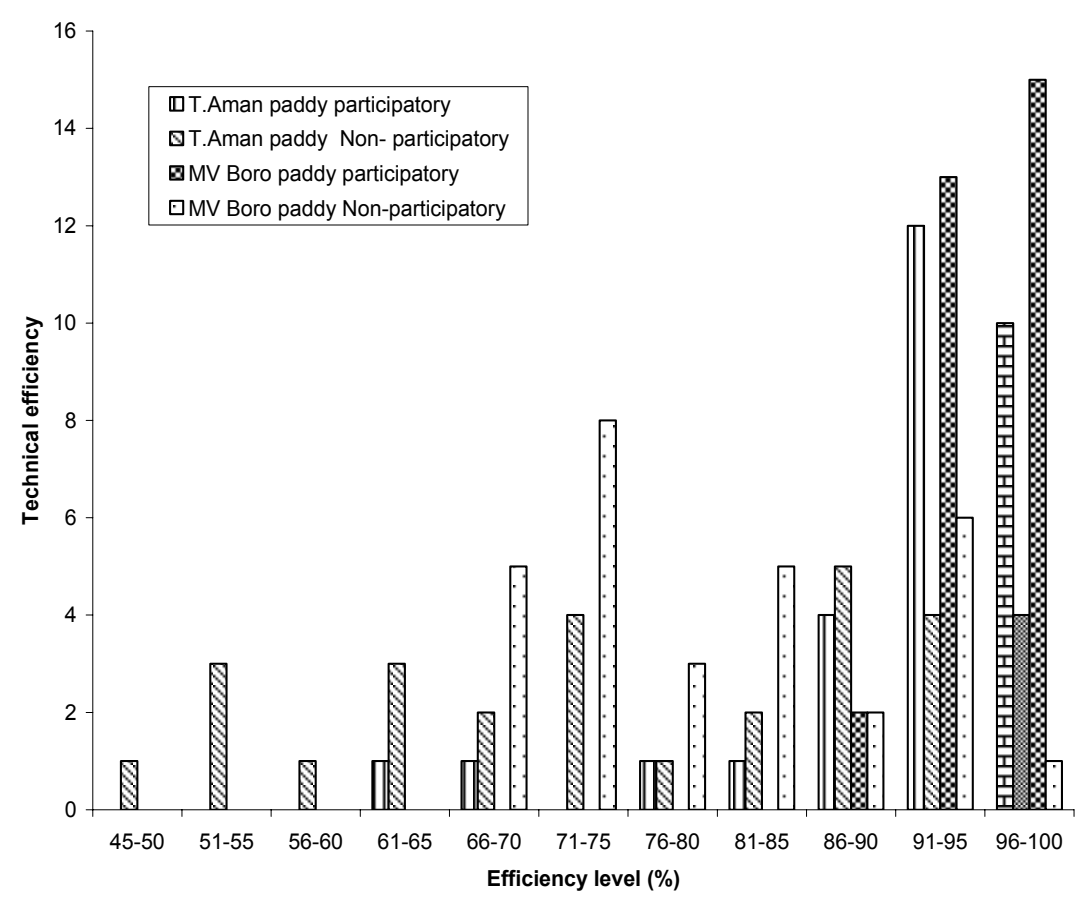

Figure 1: Technical efficiency for participatory and non-participatory farmers 
The picture is almost analogous to the pirganj MV Boro producers where non participatory farmer found to be 15 percent less efficient than the participatory farmers. These results clearly indicate that the participatory resource poor farmers were technically more efficient than the non participatory farmers.

\section{Test of Hypothesis}

We are now in a position to test the hypotheses for the study. The null hypothesis that the inefficiency effects are not present. $\mathrm{H}_{0}: \mathrm{Y}=\delta_{0}=---\delta_{7}=0$ and the coefficient of the variables in the model for the inefficiency effects are zero, $\mathrm{H}_{0}: \delta_{1}==---=\delta_{7}=0$ were tested using the generalized likelihood ratio statistics LR, defined by the Equation 8.It is imperative according to Coelli(1995), to perform one sided generalized likelihood ratio test when ML Estimation is involved because this test has the correct size(i.e. probability of Type I error).

The results of the hypothesis tests reveal that there are significant technical inefficiency effects in $T$. Aman and MV boro production. Since the null hypothesis is rejected. This indicates that the average response function is not an adequate representation for rice production in the study areas.

Another null hypothesis, $\mathrm{H}_{0}: \delta_{1}==---=\delta_{7}=0$ considered in Table 5 is also rejected for the two rice crop production. Hence, it could be concluded that the inefficiency effects are significantly influenced by the variables included in the inefficiency model.

Table 5. Test of hypothesis for coefficients of the explanatory variable for the technical inefficiency effects in the Cobb-Douglas stochastic frontier production functions

\begin{tabular}{|l|c|c|c|c|}
\hline Null hypothesis & Log likelihood value & Test statistics LR & Critical value & Decision \\
\hline $\mathrm{H}_{0}: \mathrm{V}=\delta_{0}=---=\delta_{7}=0$ & -109.57 & 25.34 & 15.51 & Reject $\mathrm{H}_{0}$ \\
$\quad \begin{array}{l}\text { T.Aman } \\
\text { MV Boro }\end{array}$ & -48.33 & 17.98 & 15.51 & Reject $\mathrm{H}_{0}$ \\
\hline $\mathrm{H}_{0}: \delta_{1}=---=\delta_{7}=0$ & -105.24 & 23.56 & 14.07 & Reject $\mathrm{H}_{0}$ \\
T.Aman & -42.29 & 15.87 & 14.07 & Reject $\mathrm{H}_{0}$ \\
MV Boro &
\end{tabular}

\section{Conclusion}

Results of the study show that the participatory farmers of Pirganj areas earned higher returns than nonparticipatory farmers from T.Aman and MV Boro rice. It was observed that the participatory farmers were assisted by the ICM project. They got material as well as logistic support from the project. Moreover, they strictly followed the training and advice provided by the project personnel. Whereas, the non-participatory farmers did not have this sort of support and help from anybody/ anywhere and they followed the traditional farming system. As a result, per ha yield and crop production efficiency (technical efficiency) of participatory farmers were higher than non- participatory farmers. Therefore, it could be concluded that the resource-poor participatory farmers of ICM project under Pirganj upazila were more efficient than the non participatory farmers.

\section{References}

Coelli, T.j. 1992. “A Computer Program for Frontier Production Function Estimation: FRONTIER, Version2.0” ,Economics letters 39: 29-32.

Coelli, T.j. 1994. "A Monto Carlo Analysis of the stochastic Frontier Production Function", mimeo, Department of Econometrics, University of New England, Armidale.

Coelli, T.j. 1995. "Recent Development in Frontier Estimation and Efficiency Measurement", Australian J. of Agricultural Economics, 39: 219-245.

Coelli, T. and Battese, G. 1996. "Identification of factors which influence the technical inefficiency of Indian Farmers", Australian J. of Agricultural Economics, 40(2): 103-128.

Farrell, M.j. 1957. "The Measurement of Productive Efficiency", Journal of the Royal Statistical Society, Series A, 120: 253-290.

Kopp, R.j and Smith, V.K. 1980. Frontier production estimates for steam electric generation: a comparative analysis", south.Econ.j.,47; 1049-1059. 
Rahman, K.M.M., Schmitz, P.M. and Wronka, T.C. 1999. "Impact of farm-specific Factors on the Technical Inefficiency of Producing Rice in Bangladesh", Bangladesh Journal of Agricultural Economics, 22,2(December): 43-56.

Rashid, M.H.A and Chen, J-r. 2002. "Technical Efficiency of Shrimp Farmers in Bangladesh; A Stochastic Frontier Production Function Analysis", Bangladesh Journal of Agricultural Economics, 25,2(December): 17-32.

Sharif, N.R and Dar, A.A. 1996. An Empirical study of the patterns and Source of Technical Efficiency in Traditional and HYV rice cultivation in Bangladesh J. Develop.Stud.32(2) : 612-629.

Stigler, C.J. 1976. The existence of X- Efficiency. Am. Econ. Review, 66, 213-226.

Sumy, M.C. 2003. Relative farming Efficiency of Participatory \& Non-Participatory resource-poor farmers of integrated crop management project in north-west region of Bangladesh. M.S. Ag. Econ. Thesis, Bangladesh Agricultural University, Mymensingh, Bangladesh.

Xiaosong, Xu and Jeffrey, S.R. 1998. Efficiency and Technical Progress in Traditional and Modern Agriculture: Evidence from Rice Production in China. Agril.Econ.,18(2):57-65. 